\title{
Influence of Variable Rigidity Design of Piled Raft Foundation on Seismic Performance of Buildings
}

\author{
Yunfei Xie, Shichun Chi 1 , and Maohua Wang \\ State Key Laboratory of Coastal and Offshore Engineering, Dalian University of Technology, \\ Faculty of Infrastructure Engineering, Dalian, China
}

Correspondence should be addressed to Shichun Chi; schchi@dlut.edu.cn

Received 19 September 2019; Accepted 24 February 2020; Published 14 March 2020

Academic Editor: José Domingo Álvarez

Copyright (c) 2020 Yunfei Xie et al. This is an open access article distributed under the Creative Commons Attribution License, which permits unrestricted use, distribution, and reproduction in any medium, provided the original work is properly cited.

In order to reduce the costs and improve the overall performance of building systems, the static optimized design with variable rigidity of piled raft foundations has been widely used in recent years. Variable rigidity design of piled raft foundations that support midrise buildings in high-risk seismic zones can alter the dynamic characteristics of the soil-pile-structure system during an earthquake due to soil-pile-structure interaction. To investigate these aspects, a nuclear power plant sitting on multilayered soil is simulated numerically. The paper describes a numerical modeling technique for the simulation of complex seismic soil-pile-structure interaction phenomena. It was observed that the total shear force on top of the piles and the rocking of the raft are reduced after optimization, whereas the displacement of the superstructure is nearly unaffected. The findings of this study can help engineers select a correct pile arrangement when considering the seismic performance of a building sitting on soft soil.

\section{Introduction}

The problem of soil-pile-structure interaction (SPSI) in seismic analysis and the design of structures have become increasingly important because it may be necessary to build structures at locations with less favorable geotechnical conditions in seismically active regions. The optimized design of a pile foundation with nonuniform pile distribution (such as different pile diameters and spacing) has also been widely used in recent years to reduce costs and improve the overall performance of building systems [1-3]. The stiffness distribution and dynamic characteristics of a piled raft foundation are altered by optimization design. However, determining the seismic response of the SPSI is a complex process that involves inertial interaction between the structure and piled raft foundation, the kinematic interaction between piles and soil, and the nonlinear response of the soil to strong earthquake motion.

Although the topic of seismic SPSI has recently received considerable attention in the literature [4-12], very few works are available on the impact of the optimized design of a piled raft foundation on the seismic response of buildings. Han and Cathro [13] analyzed the response of a tall building supported by a piled foundation and showed that its seismic behavior is different from that of a similar building supported by a rigid base or shallow foundation. Theoretical results [14] have indicated that considering soil-structure interaction is necessary, particularly for important structures, to consider either beneficial or detrimental effects on the structural performance. Chu and Truman [15] studied the effects of pile spacing on soil-structure interaction and noted that although largely spaced pile groups have slightly larger pile head responses than closely spaced pile groups, the general effects of the pile spacing ratio on the seismic response of soil-pile systems are insignificant. Hokmabadi and Fatahi [16] concluded that the influence of the foundation type on building seismic performance is a major contributor to building seismic response with SPSI and therefore should be given careful consideration. Van Nguyen et al. [17] analyzed the influence of pile size and load-bearing mechanism on the seismic performance of 
buildings and showed that the type and size of the piles influence the dynamic characteristics and seismic response of the building due to interaction between the soil, piled raft, and structure. A special system with asymmetric structure was used to investigate the topic of this paper, and asymmetric structure always needs asymmetric foundations. However, asymmetric buildings are more vulnerable to earthquake hazards than symmetric buildings [18]. Although previous studies have provided valuable contributions, further investigations are essential to fully understand the influence of optimized piled raft foundations with different pile diameters and spacing on the seismic performance of asymmetric buildings due to complex SPSI phenomena.

The direct method is preferred modeling of the complex nature of SPSI in dynamic analysis $[9,17]$ and is applied in this paper. To achieve this goal, a numerical simulation of a soil-pile-structure system was performed in ANSYS 17.0 software. The effects of optimizing the design of a piled raft foundation on the response spectrum of the system, rocking of the raft, displacement of the superstructure, and total shear force on the pile heads are investigated. The results of this study can help engineers choose a favorable optimized design for the piled raft considering the seismic performance of the structure (particularly for asymmetric structures) on soft soil.

\section{Research on the Optimized Design of Piled Raft Foundations}

The optimized design of piled raft foundations has been actively investigated in recent years [19-22], focusing on the mechanisms of different pile arrangements and considering pile-soil-pile interaction under vertical loading with the aim of reducing overall project costs and reducing differential settlement. Kim et al. [20] performed an optimization with respect to the pile locations for minimizing the differential settlement of piled raft foundations. Leung et al. [23] analyzed pile length optimization for pile groups and piled rafts and determined that the benefit can be translated to economic and environmental savings, as less material is required to attain the required level of foundation performance. Letsios et al. [24] proposed a structural optimization procedure implemented in two realworld cases, both located in London, UK, to assess the efficiency of the proposed design formulation. Notably, however, the impact of optimized piled raft foundations on the seismic response of total systems has only been rarely studied.

Even though the optimized arrangement of the piles can minimize the differential settlement of piled raft foundations, it can also result in a variable rigidity distribution of the foundation system [20] (e.g., different pile spacing or pile diameters or pile lengths can result in variable rigidity distribution in the foundation). Most of the optimized design is for static load, e.g., the load from the superstructure. Whether the variable rigidity optimized design of the piled raft foundation is beneficial to structural seismic performance [23] is investigated in the present paper. Two variable-rigidity optimized design schemes for piled raft foundations are used for comparison with traditional design schemes having uniform piles.

\section{Ground Response Analysis}

In order to verify the parameters of the model chosen in this paper, the ground response analysis is needed. During this process, the widely used SHAKE 91 software is adopted to conduct equivalent linear seismic response analyses of horizontally layered soil deposits. The input data required include the thickness of each soil layer, the maximum shear wave velocity $V_{s}$, an initial estimate of the damping ratio, the weight of the soil layers, and the corresponding straincompatible shear modulus and damping. Some of the soil parameters used during this process are from a proposed practical engineering (shown in Table 1), and the shear modulus reduction and damping curves that represent the clay, sand, and rock are from a thesis [25] (shown in Figure 1).

Two $40 \mathrm{~s}$ artificial earthquake acceleration time histories are used as the excitation in two horizontal directions. The time history of the input motions in ground response analysis is shown in Figure 2, with a peak acceleration of $0.1 \mathrm{~g}$ and time interval of $0.01 \mathrm{~s}$. Motions of $17 \mathrm{~s}$ duration are used to include all of the important features of the earthquake. The input motions are loaded at the bottom of the bedrock at the same time.

After 8 steps of iterative calculation, convergence is achieved for all soil layers, and the damping ratio and equivalent shear modulus are calculated and summarized in Table 2. Although the 1D equivalent linear method has successfully been adopted in engineering practice, many engineering problems cannot be simplified to a $1 \mathrm{D}$ case but require SPSI response analysis in $2 \mathrm{D}$ or $3 \mathrm{D}$ conditions. Therefore, in the analysis, applying the equivalent material results obtained by the $1 \mathrm{D}$ equivalent linear frequency-domain analysis to the 3D finite element approach and adopting an appropriate calibration strategy to determine the viscous damping (Rayleigh damping) coefficients is proposed and successfully validated.

The finite element model (FEM) employing the ANSYS program and equivalent soil materials (Table 2) is then proposed in the ground response analysis. Viscous damping is important for describing the response of dynamic systems. Therefore, the widely used Rayleigh damping, which is proportional to a linear combination of mass and stiffness, is used in the analysis. The Rayleigh damping is expressed as follows:

$$
C=\alpha M+\beta K
$$

where $M$ and $K$ are the mass and stiffness matrices, respectively, and $\alpha$ and $\beta$ are the mass-proportional and stiffness-proportional coefficients, respectively.

Rayleigh damping provides certain mathematical conveniences and is widely used in dynamic analysis. The Rayleigh damping model illustrated in Figure 3 shows 
TABLE 1: Adopted soil parameters for the SPSI system.

\begin{tabular}{|c|c|c|c|c|c|}
\hline Soil & High level (m) & Types & $\rho_{s}\left(\mathrm{~g} / \mathrm{cm}^{3}\right)$ & $V_{\mathrm{p}}(\mathrm{m} / \mathrm{s})$ & $V_{\mathrm{s}}(\mathrm{m} / \mathrm{s})$ \\
\hline 1 & $18.44 \sim 27$ & Clay & 1.95 & 1455 & 111 \\
\hline 2 & $15 \sim 18.44$ & Sand & 2.01 & 1501 & 190 \\
\hline 3 & $13 \sim 15$ & Clay & 1.88 & 1504 & 161 \\
\hline 4 & $2 \sim 13$ & Clay & 1.98 & 1504 & 246 \\
\hline 5 & $-4 \sim 2$ & Clay & 1.91 & 1507 & 262 \\
\hline 6 & $-17 \sim-4$ & Clay & 1.98 & 1510 & 313 \\
\hline 7 & $-21 \sim-17$ & Sand & 2.03 & 1510 & 335 \\
\hline 8 & $-26 \sim-21$ & Bedrock & 2.45 & 2850 & 1569 \\
\hline
\end{tabular}
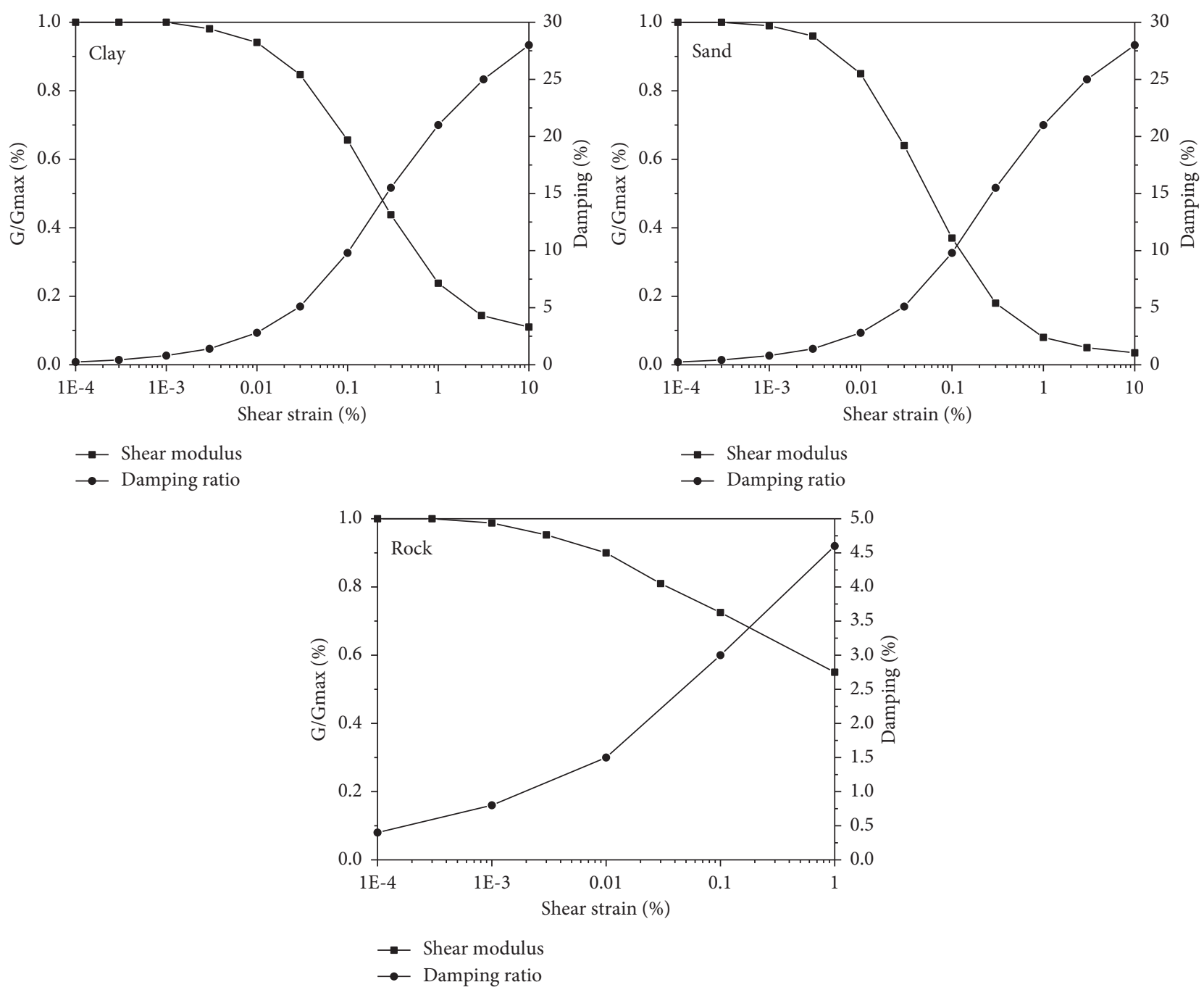

FIGURE 1: Backbone curves relating the shear stiffness and damping ration to cyclic shear strain for sand, clay, and rock.

opposite effects for the mass-proportional and stiffnessproportional damping parts regarding domination in high-frequency applications. In this paper, an appropriate calibration of the damping coefficients [27] is adopted as

$$
\left\{\begin{array}{l}
\alpha \\
\beta
\end{array}\right\}=\frac{2 \zeta}{\omega_{m}+\omega_{n}}\left[\begin{array}{l}
\omega_{m} \\
\omega_{n}
\end{array}\right]
$$

where $\omega_{m}$ is typically taken as the first natural frequency: $\omega_{1}=2 \pi f_{1}$, where $\omega_{n}$ can vary substantially [27-29], $\omega_{n}=2 \pi f_{n}$, and $f_{n}=5.6$.

The acceleration time histories and the corresponding response spectra (damping ratio $=0.07$ is the average damping ratio of the soil layers) at different layer surfaces calculated by SHAKE 91 and ANSYS are compared in Figure 4. A reasonably satisfactory match between the $1 \mathrm{D}$ SHAKE 91 and 3D FEM analyses is achieved for each soil 


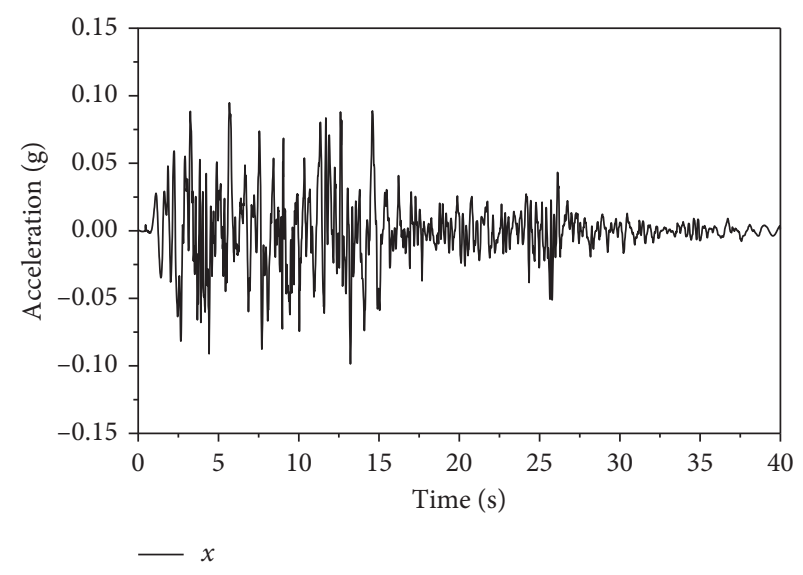

(a)

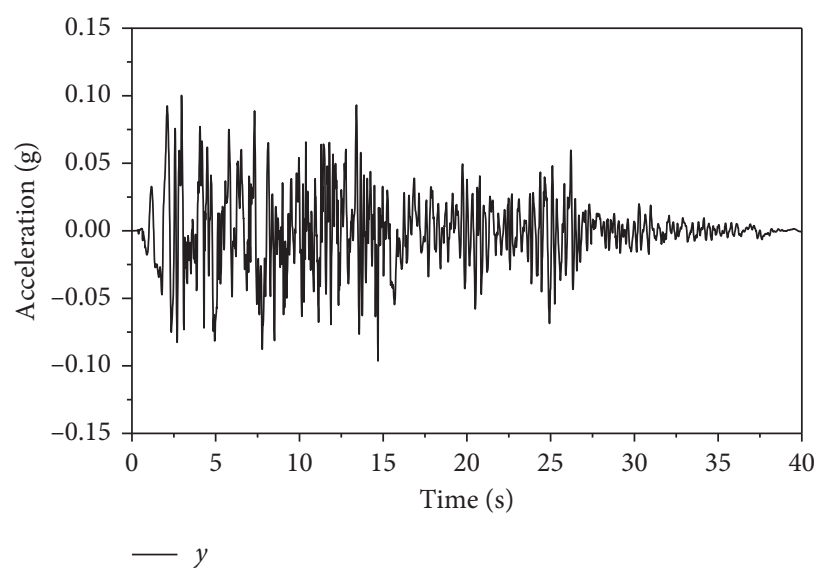

(b)

FIgURE 2: Acceleration time history of input synthetic horizontal motions.

TABLE 2: Equivalent shear modulus and damping ratio of each soil layer.

\begin{tabular}{lcc}
\hline $\begin{array}{l}\text { Layer } \\
\text { number }\end{array}$ & $\begin{array}{c}\text { Equivalent shear modulus } \\
(\mathrm{MPa})\end{array}$ & $\begin{array}{c}\text { Equivalent damping } \\
\text { ratio }(\%)\end{array}$ \\
\hline 1 & 23.0 & 0.023 \\
2 & 21.2 & 0.043 \\
3 & 19.7 & 0.058 \\
4 & 18.2 & 0.073 \\
5 & 17.1 & 0.084 \\
6 & 16.2 & 0.094 \\
7 & 40.7 & 0.065 \\
8 & 35.7 & 0.077 \\
9 & 31.1 & 0.088 \\
10 & 27.2 & 0.098 \\
11 & 24.5 & 0.110 \\
12 & 22.4 & 0.120 \\
13 & 31.1 & 0.103 \\
14 & 30.5 & 0.106 \\
15 & 96.4 & 0.062 \\
16 & 94.8 & 0.065 \\
17 & 93.3 & 0.068 \\
18 & 92.0 & 0.071 \\
19 & 91.0 & 0.073 \\
20 & 90.0 & 0.075 \\
21 & 89.1 & 0.077 \\
22 & 99.3 & 0.073 \\
23 & 98.9 & 0.074 \\
24 & 98.3 & 0.075 \\
25 & 97.8 & 0.076 \\
26 & 97.2 & 0.077 \\
27 & 96.8 & 0.078 \\
28 & 96.3 & 0.079 \\
29 & 156 & 0.062 \\
30 & 154 & 0.064 \\
31 & 153 & 0.066 \\
32 & 152 & 0.067 \\
33 & 151 & 0.069 \\
34 & 102 & 0.084 \\
35 & 101 & 0.086 \\
\hline
\end{tabular}

layer, both in terms of frequency response and acceleration time history. The difference of peak ground acceleration produced by the two methods is no more than
$10 \%$. Thus, the effectiveness of the Rayleigh damping and the analysis model are verified. The high matching of the results also showed that the linear soil model with equivalent soil material can be applied to the $3 \mathrm{D}$ FEM.

\section{Modeling Method}

ANSYS 17.0 finite element software is used to numerically simulate the SPSI system because it can simulate complex problems that require large computational memory using a direct method of analysis. Multiple researchers [18, 30, 31] have used ANSYS to study SPSI problems. The simulation of the structural elements, soil model, and boundary condition are explained below.

4.1. Modeling of the Soil-Pile-Structure System. Based on geometrical modeling, the 3D FEM of a SPSI system is developed. The model can be functionally divided into three parts: soil, piled raft foundation, and superstructure. The superstructure of the SPSI system, which has asymmetric rigidity in two directions, sits on $48 \mathrm{~m}$ deep multilayer soft soil. The superstructure is simulated by beam, pipe, and mass elements, whereas the raft, piles, and soil are modeled with solid elements (continuum elements). During the simulation of the soil medium, to reduce the effect of boundary conditions on the dynamic response of the system, the lateral model boundary is chosen as approximately 4 times the lateral size of the raft in the $x$ and $y$ directions [32], and the bottom of which is $5 \mathrm{~m}$ below the top of the bedrock. The final size of the 3D soil model is set as $322 \mathrm{~m} \times 223 \mathrm{~m} \times 53 \mathrm{~m}$, as shown in Figure 5 .

The mesh is suitably refined near the soil-raft and soilrock interfaces and in the portion of soil around the piles. The formation of a gap along the soil-pile and soil-raft interfaces is excluded, and the system behavior is idealized as linear elastic, as suggested by other researchers [18, 30, 31]. The joints between the raft and pile are modeled with rigid contacts. We assume that the superstructure and the raft are connected through a rigid domain. 


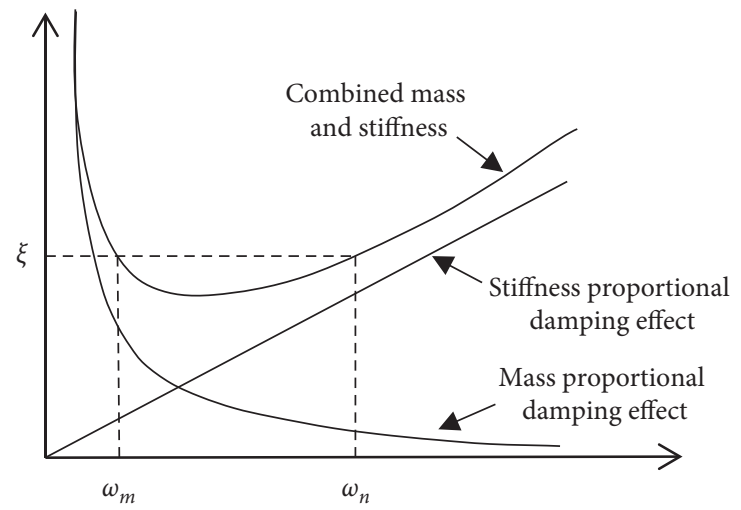

FIGURE 3: Relationship between Rayleigh damping ratio and frequency [26].
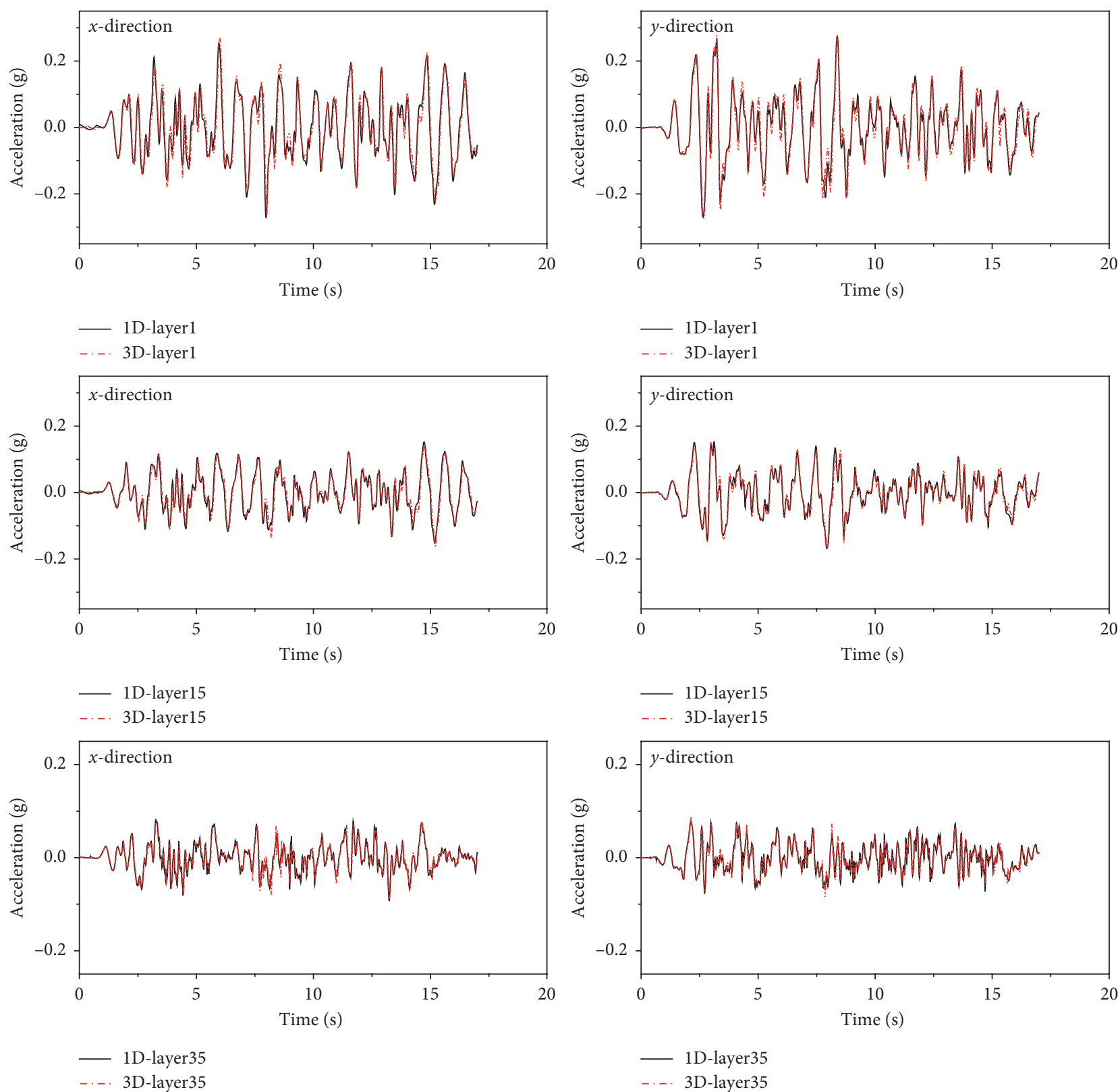

(a)

Figure 4: Continued. 

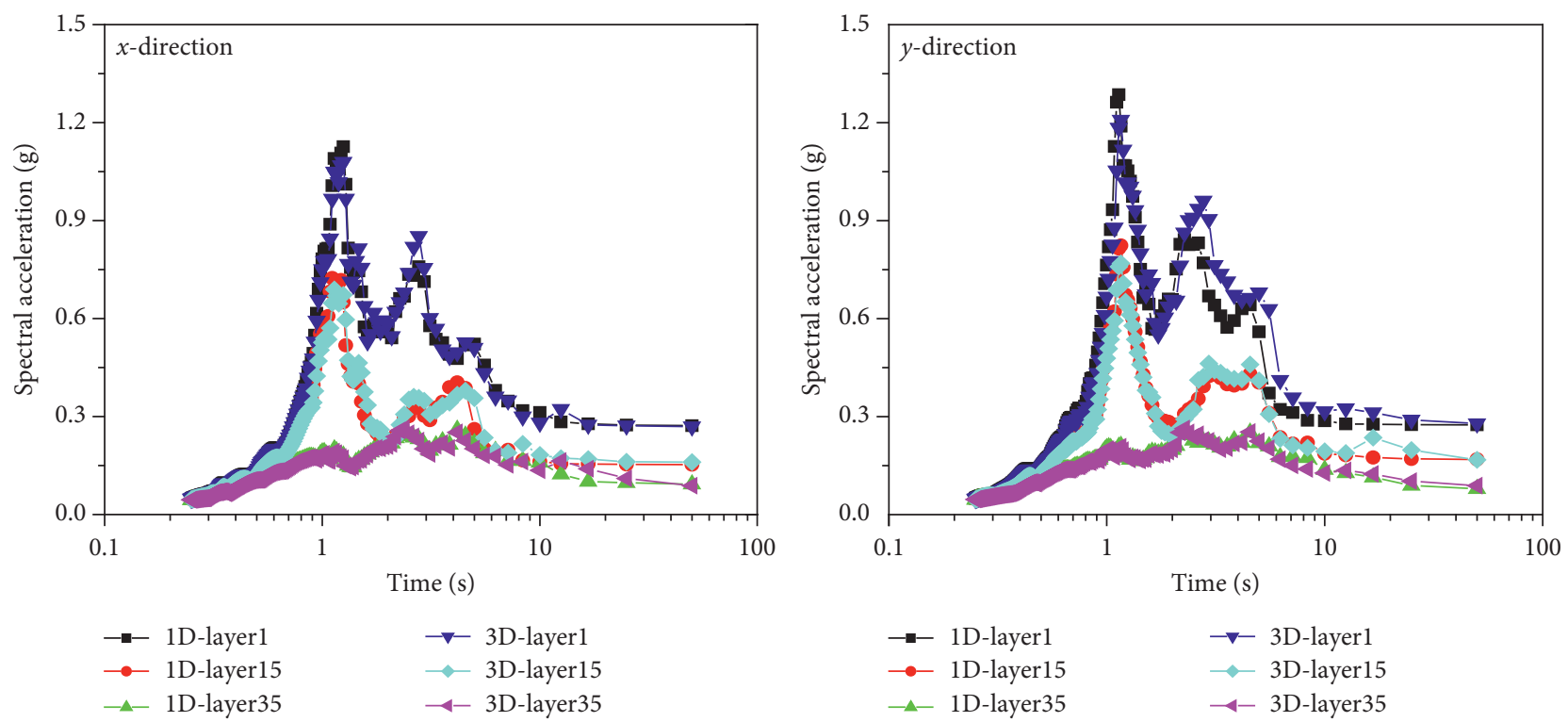

(b)

FIGURE 4: Comparison of acceleration versus time history and corresponding response spectra for 1D (SHAKE 91) and 1D (ANSYS) at different soil layers: layer 1; layer 15; layer 35. (a) Time-history acceleration records. (b) Response spectra.

The piled raft foundations are designed to support the structure against static and dynamic loads to satisfy the requirements for bearing capacity and maximum settlement. The raft is $78 \mathrm{~m}$ long, $53 \mathrm{~m}$ wide, and $1.8 \mathrm{~m}$ thick and made of reinforced concrete. As an initial design, the raft is connected to a group of 211 piles, $1.5 \mathrm{~m}$ in diameter, and $37 \mathrm{~m}$ in length, shown in Figure 6. The piles are approximately $4 \mathrm{~m}$ apart center to center (3D), which fundamentally agrees with the dimensions used by other researchers [33,34]. In order to illustrate the problem, two variable rigidity optimized design schemes (scheme 1 and scheme 2) of the piled raft foundations are adopted in here, the details of which are in the literature [35]. The pile arrangements of the two schemes are shown in Figure 7. The three schemes (containing the initial design scheme) have the same pile length and whole pile volume, in which scheme 1 has the same pile spacing with different diameters and scheme 2 has the same pile diameter but different spacing (the range of pile spacing of which is from $3.2 \mathrm{~m}$ to $6 \mathrm{~m}$ ). In this study, the piled raft foundations are modeled by 3D 8-node hexahedron solid elements. Each node has six degrees of freedom: translations in the $x, y$, and $z$ directions and rotations about $x-, y$-, and $z$-axes.

It is challenging for the high-frequency component of the shear wave to transmit from the bottom to the ground surface when the height of soil elements is too large. However, an excessively small soil element height can significantly increase the number of elements reducing computation efficiency. It has been reported that in the case of a shear wave transmitted vertically, the soil element height can be taken as $(1 / 5-1 / 8) V_{s} / f_{\max }$, in which $V_{s}$ is the velocity of the shear wave and $f_{\max }$ denotes the highest wave frequency considered. The horizontal height of elements is not as strict as the vertical dimension and is chosen to be approximately $3-5 h_{\max }$. Note that the same surrounding soil mesh was used for every scheme to compare the results for piled rafts with different arrangements to avoid the challenges associated with meshing the near-field soil variables. The surrounding soil gradually changes element sizes. The elements near the piled raft are $2.7 \mathrm{~m}$ in the horizontal direction; far from the piled raft, they are $6 \mathrm{~m}$, which results in approximately 300 thousand elements and 320 thousand nodes in the SPSI system. The seismic model excitation in this part is the same as in the ground response analysis, applied to the bottom boundary of the model in the $x$ and $y$ directions. The consideration of the soil medium and the corresponding parameters are also the same as in the ground response analysis. The parameters of the piles and the raft are described in Table 3. The model components and numerical mesh of the SPSI system are shown in Figure 5.

4.2. Boundary Conditions. Viscous-spring artificial boundaries are widely used in the analysis of site seismic response and dynamic structure-soil system interaction problems [36-38]. The boundaries of the FE model connected with a series of viscous springs ensure the absorption of the outgoing waves at the boundary. The seismic input is typically taken as equivalent nodal forces incorporated in the viscous-spring artificial boundary, and stress in the control area of any artificial boundary is considered to have uniform distribution. COMBIN14 elements are used to model the viscous-spring elements, as shown in Figure 8. The parameters of the physical elements on the nodes of the viscous-spring artificial boundary are described as follows: 


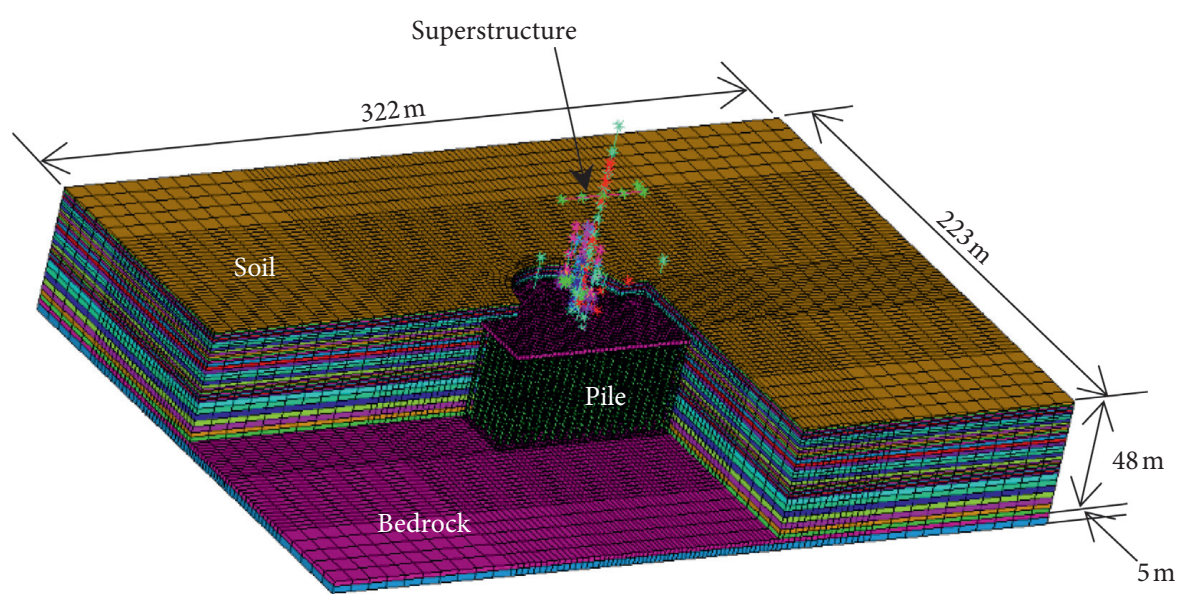

(a)

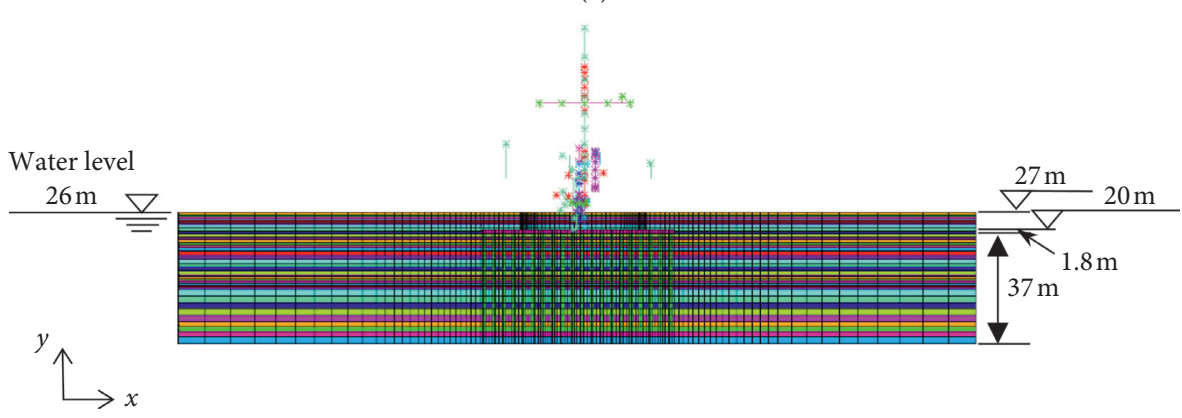

(b)

Figure 5: Nuclear power plants in ANSYS software. (a) Meshed model. (b) Sectional view.

$$
\begin{aligned}
\text { shear } \quad K_{1} & =K_{2}=\frac{2 G}{R} \sum_{i=1}^{I} A_{i}, \\
C_{1} & =C_{2}=\rho c_{s} \sum_{i=1}^{I} A_{i}, \\
\text { normal } \quad K_{3} & =\frac{4 G}{R} \sum_{i=1}^{I} A_{i}, \\
C_{3} & =\rho c_{p} \sum_{i=1}^{I} A_{i},
\end{aligned}
$$

where $K$ and $C$ are the spring and damping coefficients, respectively, and $G, \rho, c_{s}$, and $c_{p}$ are the shear modulus, material density, material shear, and longitudinal wave velocities of the transmitting media, respectively. $R$ can be regarded as the distance between the geometric center of a near-field structure and the boundary line or surface at which the artificial boundary point is located. $\sum A_{i}$ is the area represented by a node on the artificial boundary; for the situation shown in Figure 8, I=4. All five boundaries around the foundation of the SPSI system are assumed to be $3 \mathrm{D}$ viscous-spring boundaries, as shown in Figure 9, whereas earthquake input motions were applied at the bottom and propagated upward through the entire model.

\section{Results and Discussion}

5.1. Response Spectrum and Natural Frequency. The SPSI interaction is defined as a phenomenon in which soil response influences pile motion and the structure and the structural response influences the motion of the soil and the piles [39]. The impact of the SPSI on soil movement can be illustrated using the response spectrum of ground motions recorded at the base of the structure supported by a piled raft foundation. The response spectra of different schemes in the two directions are shown in Figure 10. A better understanding of the actual ground movement during an earthquake, which is challenging for free-field motion, can help the design engineer evaluate the foundation input motion (FIM) and analyze the results. The static optimized design of the piled raft foundation influences the earthquake motion at the base of the structure by altering inertial and kinematic interaction.

The response spectrum presents the peak acceleration of a single-degree-of-freedom (SDF) system with $7 \%$ damping and different natural periods for the adopted ground motions. Response spectrums are commonly used to apply structural dynamics to structure design and calculate the lateral forces required (based shears) in building codes as a function of the natural frequency of the system. Relative to the initial design with a uniform pile arrangement, the optimized piled raft foundation design causes the spectral acceleration to decrease as the natural 

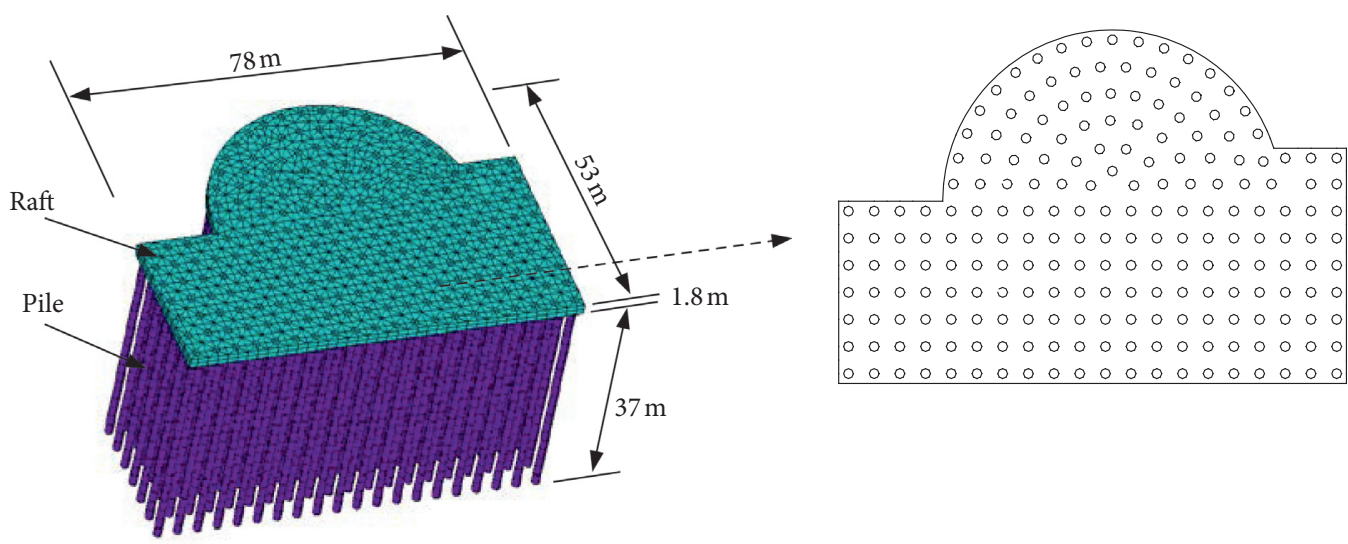

FIGURE 6: Schematic diagram of the relationship between piles and raft in initial design.

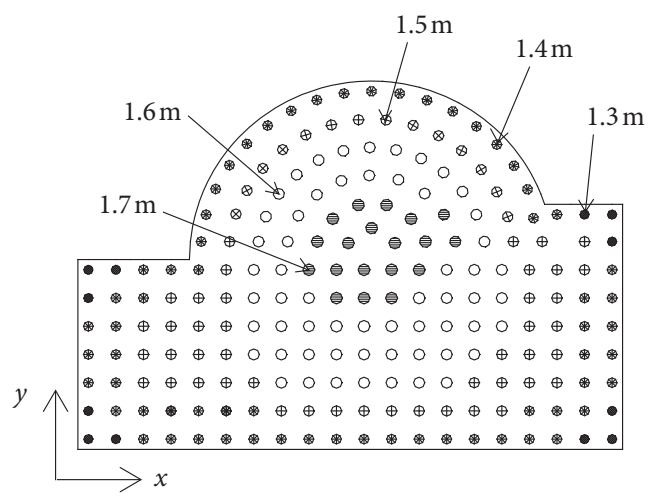

(a)

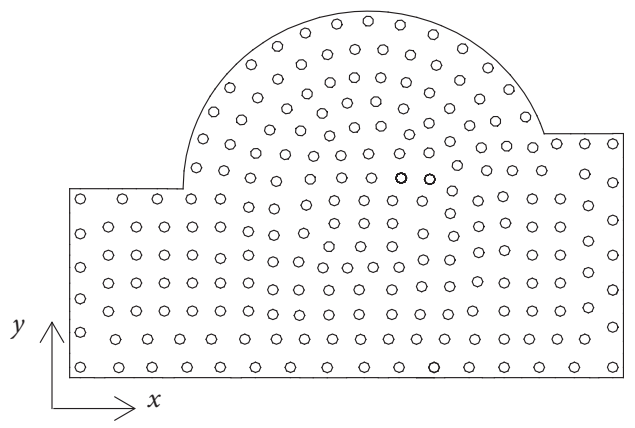

(b)

Figure 7: Pile arrangements of the two optimized design schemes. (a) Scheme 1: different pile diameters (b) Scheme 2: different pile spacing.

TABle 3: Parameters of pile, raft, and bedrock.

\begin{tabular}{lccc}
\hline & Elastic modulus $(\mathrm{Pa})$ & Poisson's ratio & Density $\left(\mathrm{kg} / \mathrm{m}^{3}\right)$ \\
\hline Pile & $3.0 E 10$ & 0.17 & 2400 \\
Raft & $2.0 E 10$ & 0.17 & 2400 \\
Bedrock & $1.549 E 10$ & 0.28 & 2450 \\
\hline
\end{tabular}

period lengthened, and this increase in the natural period changes the spectral acceleration $\left(S_{a}\right)$ response. Where buildings with piled raft foundations rest on deposits of soft soil, their natural period lies in the long region of the acceleration response spectrum curve. Because of natural period lengthening induced by the optimized design of the piled raft foundation, the spectral acceleration $\left(S_{a}\right)$ decreases, which then reduces the total shear force to at least $10 \%$ (the maximum total shear force in the time history) on top of the piles (Figure 11). The maximum accelerations of the base of the structure in two directions are all reduced after optimizing the design as shown in Figure 12, and the value of the reduction in the $y$ direction is slightly bigger than in the $x$ direction. However, the maximum total shear force on the piles in the $y$ direction has less reduction than in the $x$ direction due to the complex SPSI. Thus, the static optimization of a piled raft foundation can change its

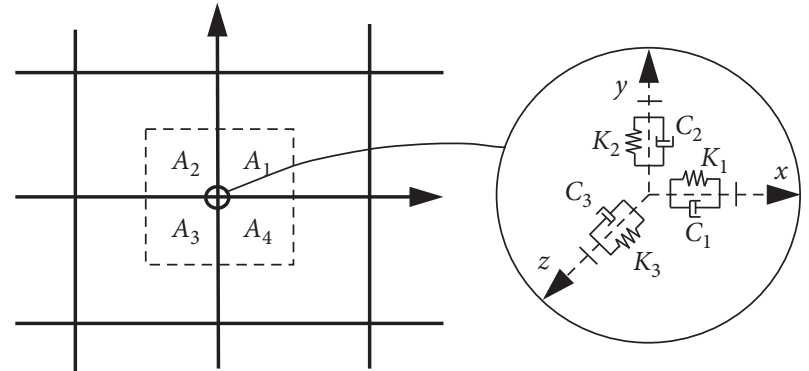

Figure 8: Three-dimensional viscous-spring boundary.

stiffness distribution. Moreover, the shape of the raft or pile arrangement can change this optimization effect.

5.2. Rocking of the Piled Raft Foundation. The piled raft in this system is asymmetric in two directions due to the asymmetric superstructure; thus, the maximum foundation rocking cannot be in only one direction and must be the result of combined action in two directions. The foundation rocking in this paper is the absolute value of the raft maximum rocking. Figure 13 shows how a piled raft foundation supporting a $60 \mathrm{~m}$ high structure rocked over 


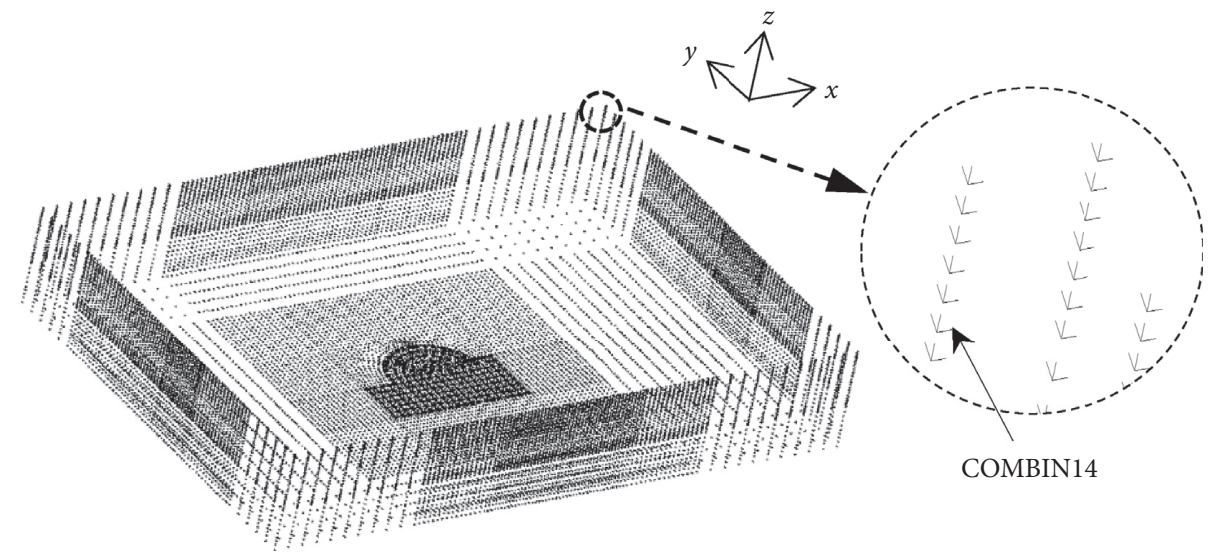

FIgURE 9: Distribution of the 3D viscous-spring boundary around the foundation.
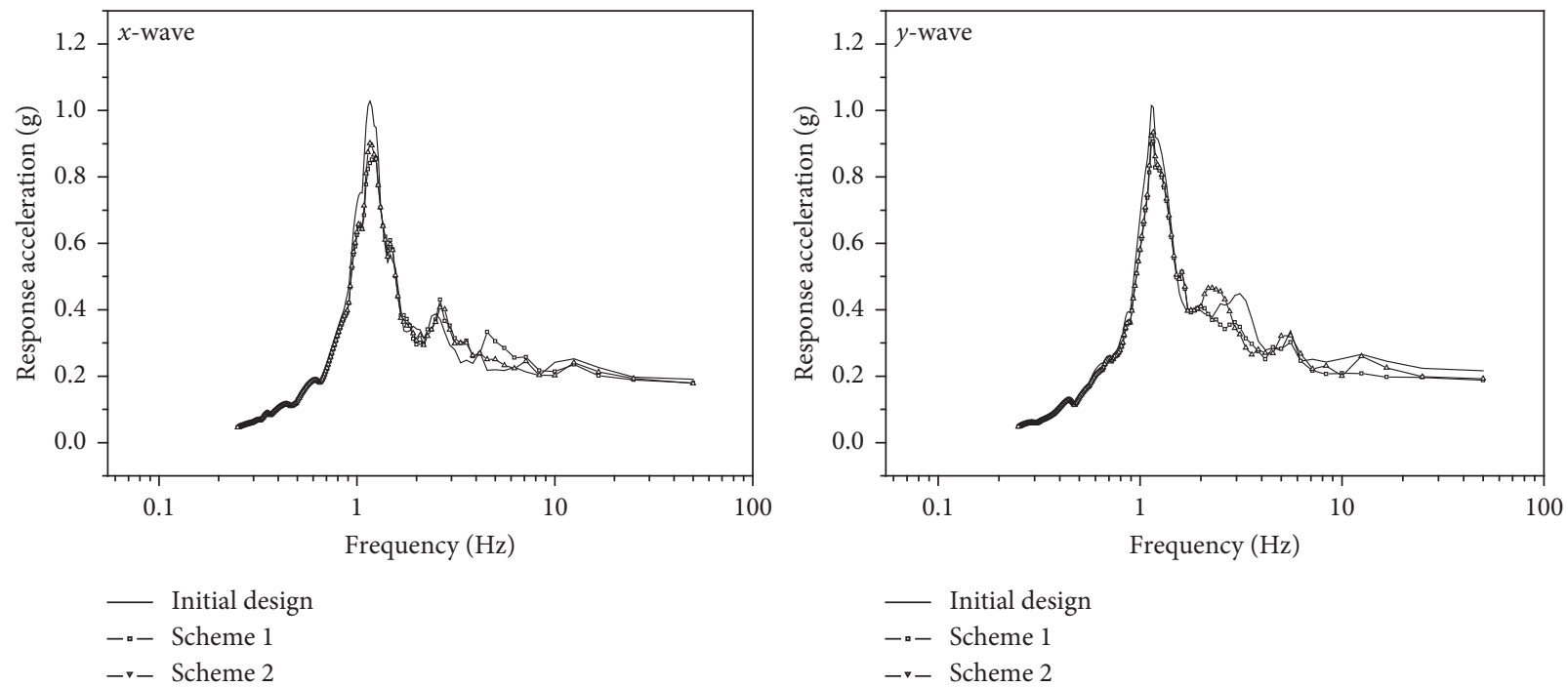

FIGURE 10: Comparison of response spectrum of the base of the structure in two directions during different schemes.

time. Rocking occurs when the inertial forces generated in the superstructure cause compression on one side of the structure and tension on the other, which then results in settlement on the one side and possible uplift on the other side. The models that underwent the same earthquake (albeit with varied pile arrangements) exhibited a similarly shaped rocking model over time. The maximum rocking of different cases with different pile arrangements under earthquake excitation is summarized in Figure 14.

There was less rocking after static optimized design than for the initial design. One reason is that the resistance center of the piled raft foundation after static optimized design better coincided with the mass center of the superstructure resulting in less rocking. For example, the maximum rocking gradually decreased from 0.0203 to 0.0168 degrees after optimized design with different pile diameters and from 0.0203 to 0.0198 degrees after optimized design with different pile spacing. These results indicated that regardless of the pile diameters or spacing, the nonuniform pile replacement in the foundation results in nonuniform

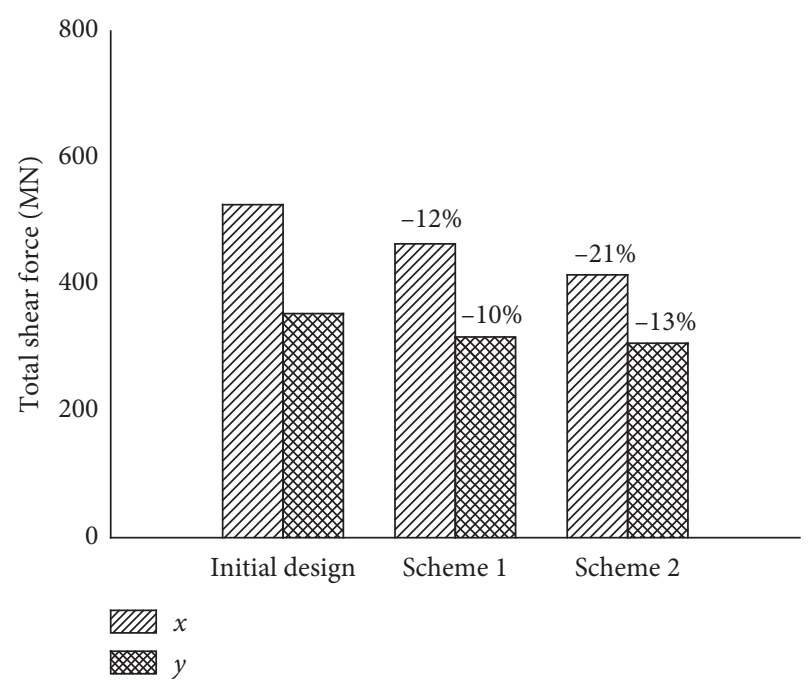

FIGURE 11: Comparison of maximum total shear force on top of piles for different schemes in two directions. 


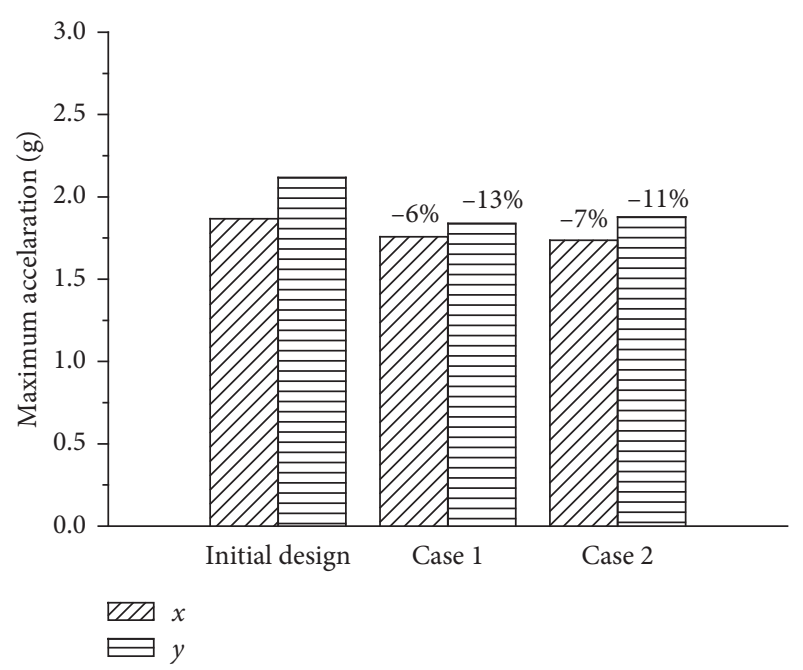

FIGURE 12: Comparison of maximum acceleration of the base of the structure in two directions during different schemes.

distribution of the pile resistance. A reasonable pile foundation stiffness distribution can result in less rocking of the raft and then reduce this reaction for the superstructure.

5.3. LateralDisplacement of the Superstructure. To determine the effect of the different pile arrangements on the displacement response of the superstructure and soil, the distribution of the maximum lateral superstructure and soil displacements for different schemes are presented in Figure 15. Similarly, the maximum lateral displacement of each observation point is determined when the maximum displacement at the top of the structure occurs.

The lateral displacement of the soil changes slightly after optimizing the piled raft foundation design, indicating that the horizontal stiffness from the three schemes is similar. However, for scheme 1, starting from the top of the soil layer, the lateral displacement of the superstructure is substantially reduced in both directions. For scheme 2, the superstructure displacement is still similar to the initial design. The superstructure displacement always absorbs various complex factors, such as kinematic and inertial interaction. One reason can be found in Figure 12. The maximum acceleration of the structure base, which is also the maximum acceleration on top of the raft, is reduced after static optimized design, which then transfers less acceleration resulting in less displacement of the superstructure. From this point, scheme 1 with different pile diameters is slightly better than scheme 2.

5.4. Acceleration Magnification Coefficient. Static optimized design with nonuniform pile placement in the soil of the piled raft foundation can change the distribution of foundation internal stiffness, which then changes the form and size of the seismic load transmitted to the bottom of the superstructure. In this part, some observation points are taken along the model at different heights. The amplification factors of peak acceleration for the finite element analyses of

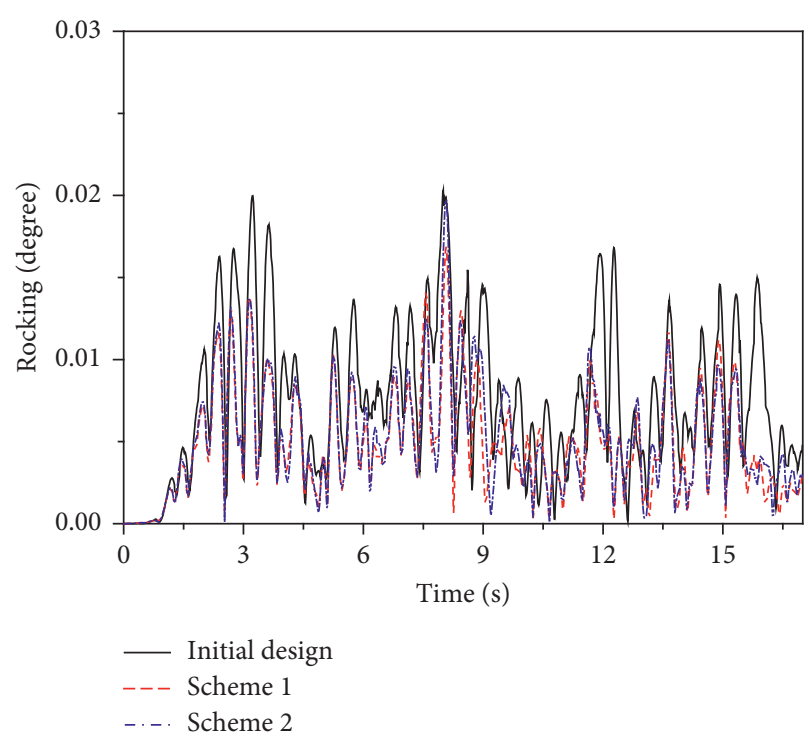

FIGURE 13: Rocking time history in three schemes.

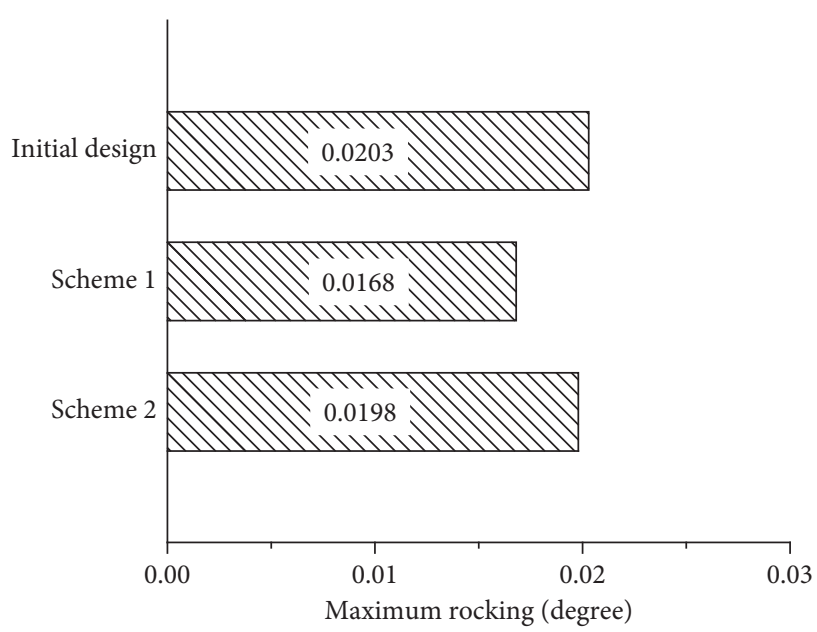

Figure 14: Comparison of maximum foundation rocking for different schemes in two directions.

these points can be obtained, which is the result compared with the bottom acceleration peak. The curve of the acceleration amplification factor of the points from the soil and superstructure at different heights under different conditions are shown in Figure 16.

The acceleration amplification factor of the soil decreases gradually as the distance between the point and the ground increases, while the superstructure response increases gradually. After static optimized design, the change of soil amplification on the input seismic wave is slight; however, the amplification of the superstructure changes substantially. Scheme 2 results in a smaller acceleration amplification factor than scheme 1 in the $x$ direction, but scheme 1 produces a large decrease in the $y$ direction. Asymmetric structures result in different effects in different directions after optimized design. The results indicate that the main reason for the reduced system response after optimized design is not the increasing stiffness of the piled raft foundation (because the underground 

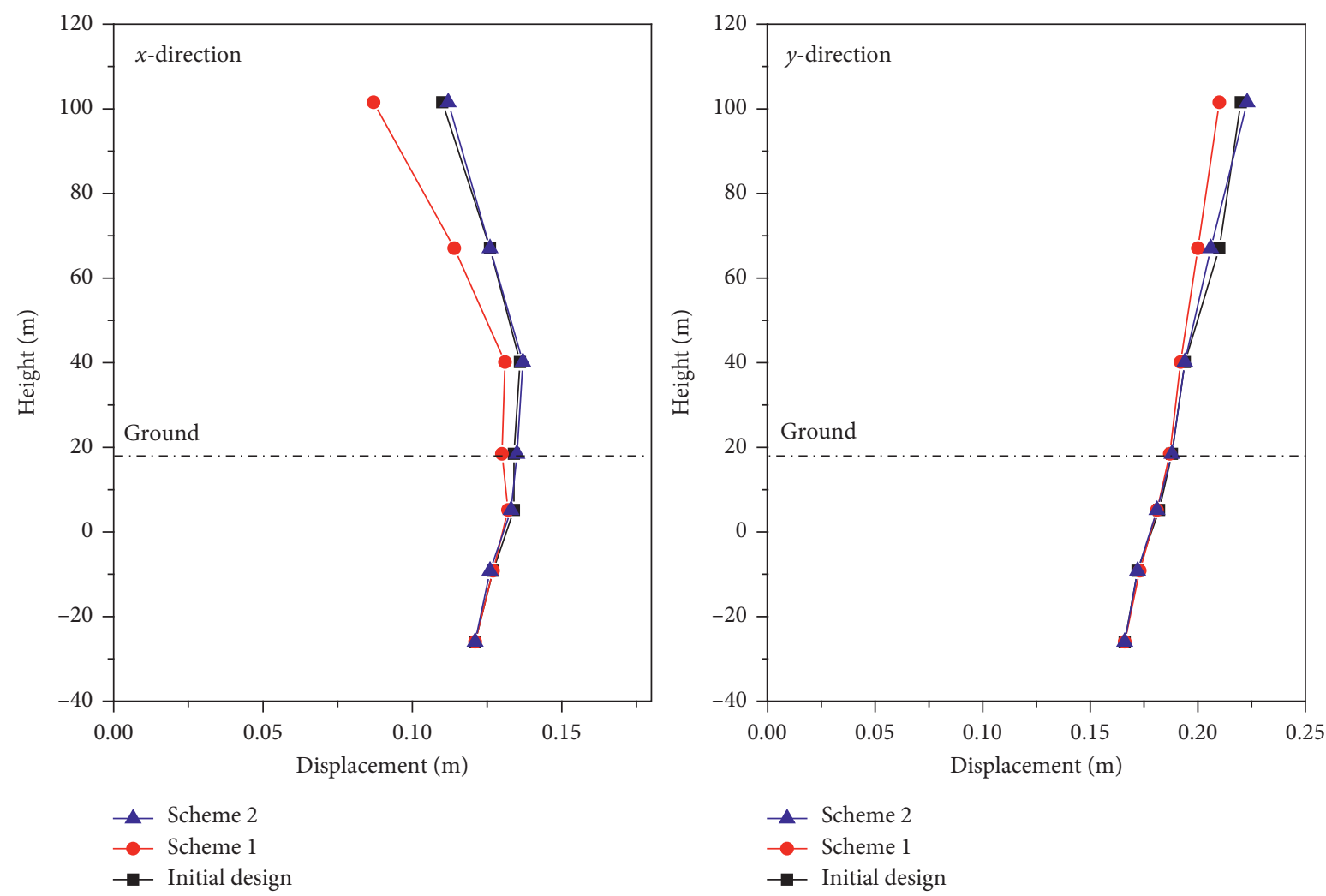

Figure 15: The maximum lateral displacement of the superstructure and soil in different schemes.
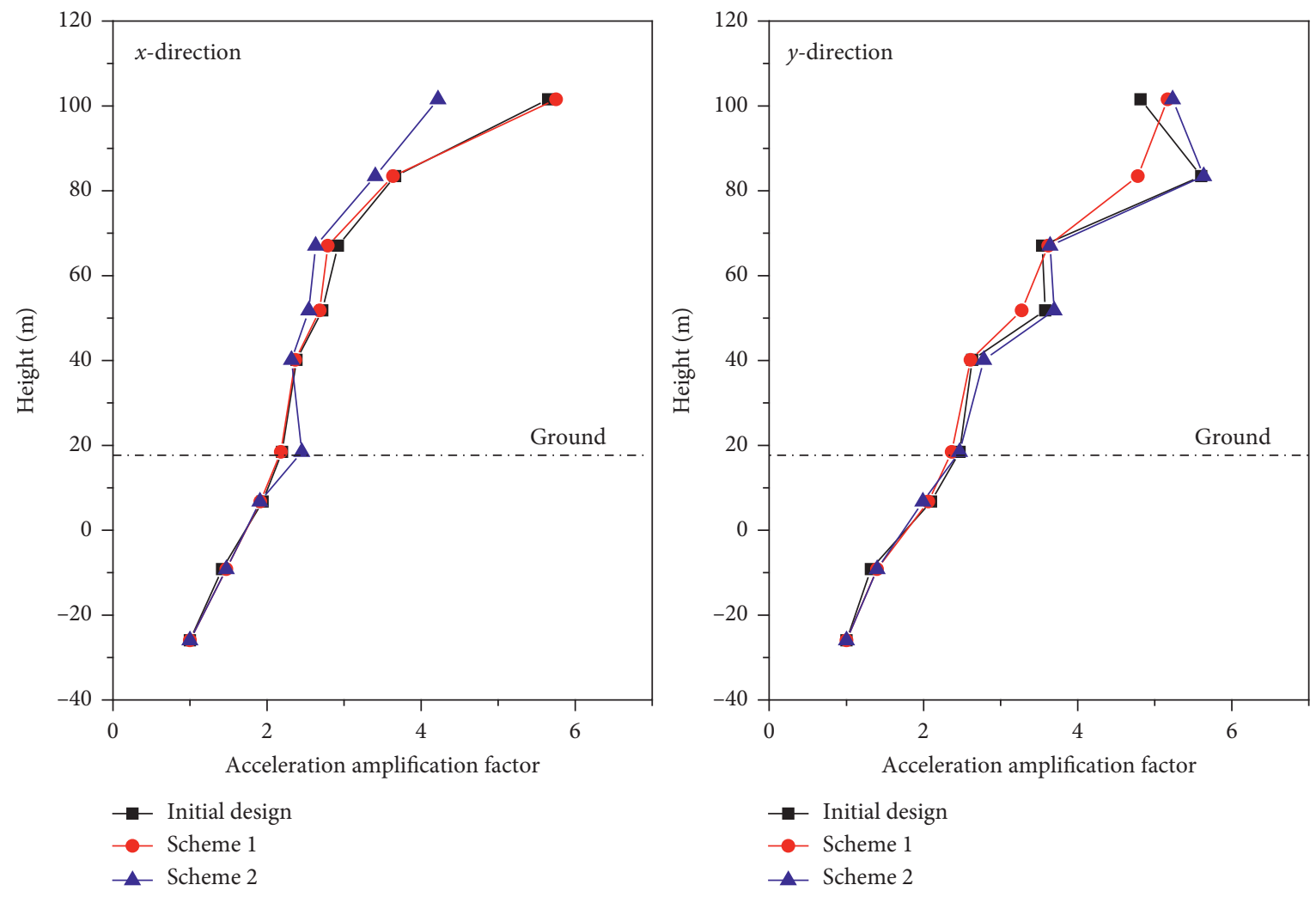

FIgURE 16: Acceleration amplification factor of observation points in different models. 
amplification factors of acceleration do not change substantially) but the optimization of the stiffness distribution in the foundation system. The reason is that the optimized schemes make the foundation system stiffness distribution accommodate the superstructure load better than the case of uniform pile arrangements. The foundation has a different stiffness in two directions, resulting in different optimization effects in the two directions from different schemes, indicating that the raft shape is also a significant factor.

\section{Conclusions}

In this paper, 3D finite element analyses of an SPSI system based on equivalent linear soil material parameters were carried out. To investigate the effect of the static optimized piled raft foundation design on the SPSI system in high-risk seismic zones, three models with different pile arrangements were simulated numerically using ANSYS software. The effects of static optimized design on the dynamic response of the system are assessed in detail. Important conclusions drawn from the analyses are as follows:

(1) The ground response results obtained from the 3D $\mathrm{FE}$ analyses with the equivalent linear soil material from the last step of the $1 \mathrm{D}$ equivalent linear analyses are in satisfactory agreement with the $1 \mathrm{D}$ results.

(2) A reasonable static optimized design can suppress piled raft foundation rocking, which comes from the superstructure mass not being coincident with the center of the pile group resistance and the reduction in the displacement response of the soil and superstructure during the interaction between the soil and piles. Moreover, the optimized design with different pile diameters is slightly better than the results of different pile spacing in terms of the structural dynamic response.

(3) The structure lateral deflection arises from two components: structural distortion, corresponding to the shear deformation generated in the structure, and foundation rocking. This study shows that the static optimized design of the piled raft foundation makes the resistance center better coincide with the superstructure mass center, which reduces foundation rocking. The lateral deformation of the structure and the total shear force on top of the piles are also reduced.

(4) The displacement and acceleration amplification factor do not change substantially in the soil, indicating that the static optimized design does not change the stiffness of the piled raft foundation obviously relative to the uniform design method. However, the effect of the superstructure is relatively strong, indicating that the foundation load has changed. One possible reason is that the horizontal stiffness distribution of the pile foundation is brought to a favorable state through optimized design and is more suitable for resisting the superstructure inertial forces. However, this phenomenon is the result of multiple complex factors and will be discussed in another paper.
In summary, determination of seismic response in the SPSI system is a complex process including the nonlinearity of soil, the kinematic interaction between the soil and piles, and the inertial interaction between the soil and structure. Broadly, the study indicates that static optimization may not increase the stiffness of the piled raft foundation but that a better horizontal stiffness distribution is also beneficial for the response of the structure. The reasonable use of materials to make the structure achieve an optimal state of stress is a long-term research topic. Vertical seismic waves were not considered in this study, and the influence of the optimized design under the action of vertical seismic waves also requires additional research. Further research will be conducted to a dynamic optimization design method for the whole SPSI system. This study is based on fundamental modeling of the elastic range behavior of both structural and foundation elements, and this behavior is addressed only summarily. However, the results presented in this paper provide a global understanding of this SPSI system under seismic loading and offer useful data and references for the seismic design of SPSI systems in the future.

\section{Data Availability}

The data used to support the findings of this study are available from the corresponding author upon request.

\section{Conflicts of Interest}

The authors declare that there are no conflicts of interest regarding the theoretical and numerical observations introduced in this paper.

\section{Acknowledgments}

This work was supported by the National Key Research and Development Project in China (grant no. 2016YFB0201001).

\section{References}

[1] Y. K. Chow and V. Thevendran, "Optimisation of pile groups," Computers and Geotechnics, vol. 4, no. 1, pp. 43-58, 1987.

[2] J. L. Liu and L. Q. Chi, "The modified model of pile-soil deformation calculation and variable rigidity design method for balance settlement," Chinese Jounal of Geotechnical Engineering, vol. 22, no. 2, pp. 151-156, 2000.

[3] K. Z. Truman and A. S. Hoback, "Optimization of steel piles under rigid slab foundations using optimality criteria," Structural Optimization, vol. 5, no. 1-2, pp. 30-36, 1992.

[4] B. Zhao, Y. Liu, S. H. Goh, and F. H. Lee, "Parallel finite element analysis of seismic soil structure interaction using a PC cluster," Computers and Geotechnics, vol. 80, pp. 167-177, 2016.

[5] R. Saha, S. C. Dutta, and S. Haldar, "Seismic response of soilpile raft-structure system," Journal of Civil Engineering and Management, vol. 21, no. 2, pp. 144-164, 2015.

[6] S. C. Dutta, R. Saha, and S. Haldar, "Inelastic seismic behavior of soil-pile raft-structure system under bi-directional ground motion," Soil Dynamics and Earthquake Engineering, vol. 67, pp. 133-157, 2014. 
[7] Z. Han, G. Lin, and J. Li, "Dynamic 3D foundation-soil-foundation interaction on stratified soil," International Journal of Structural Stability \& Dynamics, vol. 17, no. 3, Article ID 1750032, 2016.

[8] S. C. Dutta and R. Roy, "A critical review on idealization and modeling for interaction among soil-foundation-structure system," Computers \& Structures, vol. 80, no. 20-21, pp. 1579-1594, 2002.

[9] C. Luo, X. Yang, C. Zhan, X. Jin, and Z. Ding, "Nonlinear 3D finite element analysis of soil-pile-structure interaction system subjected to horizontal earthquake excitation," Soil Dynamics and Earthquake Engineering, vol. 84, pp. 145-156, 2016.

[10] M. Iida, "Three-dimensional finite-element method for soilbuilding interaction based on an input wave field," International Journal of Geomechanics, vol. 13, no. 4, pp. 430-440, 2013.

[11] J. Bielak and P. Christiano, "On the effective seismic input for non-linear soil-structure interaction systems," Earthquake Engineering \& Structural Dynamics, vol. 12, no. 1, pp. 107-119, 1984.

[12] M. Iida and Y. Furumoto, "3-D nonlinear soil-building interaction analysis during the hypothetical guerreo earthquake in the lakebed zone of Mexico city," in Summaries of Technical Papers of Meeting Architectural Institute of Japan. B-2, Structural Dynamics Nuclear Power Plants, pp. 343-344, Architectural Institute of Japan, Tokyo, Japan, 1997.

[13] Y. Han and D. Cathro, "Seismic behavior of tall buildings supported on pile foundations," in Proceedings of the Seismic Analysis and Design for Soil-Pile-Structure Interactions, ASCE, Minneapolis, MN, USA, pp. 36-51, October 2011.

[14] G. Mylonakis and G. Gazetas, "Seismic soil-structure interaction: beneficial or detrimental?" Journal of Earthquake Engineering, vol. 4, no. 3, pp. 277-301, 2000.

[15] D. Chu and K. Z. Truman, "Effect of pile foundation configurations in seismic soil-pile-structure interaction," in Proceedings of the 13th Word Conference on Earthquake Engineering, p. 1551, Vancouver, Canada, August 2004.

[16] A. S. Hokmabadi and B. Fatahi, "Influence of foundation type on seismic performance of buildings considering soil-structure interaction," International Journal of Structural Stability and Dynamics, vol. 16, no. 8, Article ID 1550043, 2016.

[17] Q. Van Nguyen, B. Fatahi, and A. S. Hokmabadi, "Influence of size and load-bearing mechanism of piles on seismic performance of buildings considering soil-pile-structure interaction," International Journal of Geomechanics, vol. 17, no. 7, Article ID 04017007, 2017.

[18] P. Badry and N. Satyam, "Seismic soil structure interaction analysis for asymmetrical buildings supported on piled raft for the 2015 Nepal earthquake," Journal of Asian Earth Sciences, vol. 133, pp. 102-113, 2017.

[19] D. C. N. Dang, D. S. Kim, and S. B. Jo, "Parametric study for optimal design of large piled raft foundations on sand," Computers \& Geotechnics, vol. 55, pp. 14-26, 2014.

[20] K. N. Kim, S.-H. Lee, K.-S. Kim, C.-K. Chung, M. M. Kim, and H. S. Lee, "Optimal pile arrangement for minimizing differential settlements in piled raft foundations," Computers and Geotechnics, vol. 28, no. 4, pp. 235-253, 2001.

[21] H. G. Poulos, "Piled raft foundations: design and applications," Géotechnique, vol. 51, no. 2, pp. 95-113, 2001.

[22] L. D. Sanctis, A. Mandolini, G. Russo, and C. Viggiani, "Some remarks on the optimum design of piled rafts," in Proccedings of the International Deep Foundations Congress, pp. 405-425, ASCE, February 2002, Orlando, FL, USA.
[23] Y. F. Leung, A. Klar, and K. Soga, "Theoretical study on pile length optimization of pile groups and piled rafts," Journal of Geotechnical and Geoenvironmental Engineering, vol. 136, no. 2, pp. 319-330, 2010

[24] C. Letsios, N. D. Lagaros, and M. Papadrakakis, "Optimum design methodologies for pile foundations in London," Case Studies in Structural Engineering, vol. 2, pp. 24-32, 2014.

[25] I. M. Idriss, "Response of soft soil sites during earthquakes," in Proceedings of the Memorial Symposium to Honor Professor $\mathrm{H}$. B. Seed, pp. 273-289, Berkeley, CA, USA, May 1990.

[26] R. W. Clough and J. Penzien, Dynamic of Structures, Computers and Structures, Berkeley, CA, USA, 3rd edition, 2003.

[27] Z. De-gao, X. Bin, and K. Xian-jing, "Study of influence of different methods for calculating Rayleigh damping coefficient on high earth-rock dam seismic response," Rock and Soil Mechanics, vol. 32, no. 3, pp. 797-803, 2011.

[28] N. Yoshida, S. Kobayashi, I. Suetomi, and K. Miura, "Equivalent linear method considering frequency dependent characteristics of stiffness and damping," Soil Dynamics and Earthquake Engineering, vol. 22, no. 3, pp. 205-222, 2002.

[29] I. M. Idriss, "Quad-4 : a computer program for evaluating the seismic response of soil structures by variable damping finete element procedures," Report; EERC 73-16, College of Engineering, University of California, Berkeley, CA, USA, 1973.

[30] K. J. Bentley and M. H. El Naggar, "Numerical analysis of kinematic response of single piles," Canadian Geotechnical Journal, vol. 37, no. 6, pp. 1368-1382, 2000.

[31] A. Bao, J. Lawrence, V. Hopson, and M. Puzio, "Optimization of bridge deep foundation design in seismic and tsunami zones," American Journal of Physical Anthropology, vol. 131, pp. 432-443, 2014.

[32] R. D. Laora and E. Rovithis, "Kinematic bending of fixed-head piles in nonhomogeneous soil," Journal of Geotechnical and Geoenvironmental Engineering, vol. 141, no. 4, Article ID 04014126, 2014.

[33] J. C. Small and H. H. Zhang, "Behavior of piled raft foundations under lateral and vertical loading," International Journal of Geomechanics, vol. 2, pp. 29-45, 2002.

[34] A. Shelke and N. R. Patra, "Effect of arching on uplift capacity of pile groups in sand," International Journal of Geomechanics, vol. 8, no. 6, pp. 347-354, 2008.

[35] Y. F. Xie and S. C. Chi, "Optimization method for irregular piled raft foundation on layered soil media," Advances in Civil Engineering, vol. 2019, Article ID 5713492, 15 pages, 2019.

[36] Z. Xiaolong, L. Xiaojun, C. Guoxing, and Z. Zhenhua, "An improved method of the calculation of equivalent nodal forces in viscous-elastic artificial boundary," Chinese Journal of Theoretical and Applied Mechanics, vol. 48, no. 5, pp. 11261135, 2016.

[37] L. Zhongcheng, F. Hong, and L. Jianbo, "Seismic response analysis based on dynamic artificial boundaries for nuclear power engineering," Nuclear Power Engineering, vol. 37, pp. 47-50, 2016.

[38] G. Yin, L. Jin-bo, and D. Yi-xin, "3D consistent viscous-spring artificial boundary and viscous-spring boundary element," Engineering Mechanics, vol. 24, no. 12, pp. 31-37, 2007.

[39] S. L. Kramer, Geotechnical Earthquake Engineering, McGrawHill, New York, NY, USA, 1996. 